Continuity and Change

http://journals.cambridge.org/CON

Additional services for Continuity and Change:

Email alerts: $\underline{\text { Click here }}$

Subscriptions: $\underline{\text { Click here }}$

Commercial reprints: Click here

Terms of use : Click here

\title{
Inheritance, marriage, widowhood and remarriage: a comparative perspective on women and landholding in north-east Norfolk, 1440-1580
}

JANE WHITTLE

Continuity and Change / Volume 13 / Issue 01 / May 1998, pp 33 - 72

DOI: null, Published online: 30 March 2001

Link to this article: http://journals.cambridge.org/abstract S026841609800304X

How to cite this article:

JANE WHITTLE (1998). Inheritance, marriage, widowhood and remarriage: a comparative perspective on women and landholding in north-east Norfolk, 1440-1580. Continuity and Change, 13, pp 33-72

Request Permissions : $\underline{\text { Click here }}$ 


\section{Inheritance, marriage, widowhood and remarriage: a comparative perspective on women and landholding in north-east Norfolk, 1440-1580}

JANE WHITTLE*

In medieval and early modern England, men's and women's rights to land were not equal. Sons were preferred over daughters in the inheritance of land. Marriage removed rights of property ownership from women and placed them in the hands of their husbands. Yet land stood at the heart of the economy and society in rural England in a period when agriculture was the main employer and land the main source of wealth, social status and political power. Ordinary women's inferior rights to land were a key aspect in women's subordination as a whole. The study presented here is a detailed examination of women's acquisition and possession of land in north-east Norfolk in the period 1440-1580, using data from manorial documents and wills. Erickson has noted that it is relatively easy to compile information on how women as a sex were supposed to act in early modern England, and lists of the legal restrictions placed upon them. It is much more difficult to ascertain exactly how women did behave and how they responded to their legal disabilities.' ${ }^{1}$ This study emphasizes actual practice rather than legal theory.

The women of sixteenth- and seventeenth-century East Anglia are unusually well represented in existing local studies by the work of Evans, Amussen, Wales and Botelho. However, none of these authors has utilized manorial documents, which are the main source of information on landholding patterns of medieval and early modern England. ${ }^{2}$ This is true of other studies of early modern women and property in England, with the exceptions of Todd's work on Berkshire widows and Seeliger's on female

* Department of Economic and Social History, University of Exeter. 
landholders in Hampshire. ${ }^{3}$ There is also a general tendency for early modern studies to start in 1550 or 1580 , while medieval studies finish in 1400,1450 or earlier, leaving a gap of a century or more. ${ }^{4}$ The time period on which this paper focuses stands between the disappearance of serfdom in the early fifteenth century on the one hand and the rapid increase in landlessness that marked the late sixteenth and seventeenth centuries on the other. It was a period when ordinary people were both personally free and, on the whole, in possession of land, and thus we might suppose it is an ideal period for studying popular attitudes to land and gender. The intention of this article is to fill a gap in our existing knowledge about the lives of women in pre-industrial England using an intensive local study. But it also sets women's experience of access to land in this particular locality and time period in a wider perspective. Comparisons are made over time, contrasting the fifteenth- and sixteenth-century situation with the two previous and the two subsequent centuries, and across space, comparing this locality with others in England. Patterns of landholding in medieval and early modern England were intensely local, varying not only regionally but from manor to manor. In comparing early-fourteenthcentury Brigstock in Northamptonshire with sixteenth-century Hevingham in Norfolk and with seventeenth-century Long Wittenham in Berkshire, it is possible that geographical differences in types of tenure and traditions of practice outweigh any changes in attitudes to women as landholders over time. ${ }^{5}$ If we are ever to delineate patterns of change over time and from contrasting localities, it is important to adopt a heightened awareness of local differences.

North-east Norfolk had an unusually active land market in both the medieval period and the sixteenth century, and a flexible attitude to the inheritance of land is evident in both periods. ${ }^{6}$ The court roll data discussed below come from the manor of Hevingham Bishops, situated approximately eight miles north of Norwich and comprising parts of the parishes of Marsham, Hevingham and Brampton. ${ }^{7}$ The majority of the manor's arable land was held by copyhold, and the data relate almost exclusively to copyhold land, as opposed to freehold or demesne leasehold. As was common in this part of Norfolk, tenants held by copyhold of inheritance, giving them the right to buy, sell and bequeath their land, on the payment of a small fine to the manorial lord. Entry fines in Hevingham were particularly low at between $4 \mathrm{~d}$ and $6 \mathrm{~d}$ per acre. Copyhold land rarely lay vacant in Hevingham, even in the mid fifteenth century, suggesting that contemporaries regarded it as an advantageous place to hold land. The manor had 49 tenants in c.1515 and 51 in 1540. Because the manor was spread across a number of parishes and interminged with other manors, it is impossible to estimate its resident population. Comparison 
between manorial records and Marsham's parish register provides some indication of landlessness among adult householders in the mid sixteenth century, and suggests that at least 20 per cent of men who had children christened in this period were landless permanent residents. ${ }^{8}$ The manorial surveys examined below originate from Hevingham Bishops and three nearby manors, Hevingham Cattes, Lord Morleys' lands and Saxthorpe Mickelhall. The wills used come from the parishes of Marsham, Hevingham, Brampton, Corpusty, Saxthorpe and Scottow, again situated in or near Hevingham manor. The estimated populations of these six parishes in 1522 were $207,126,45,81,172$ and 162 people, respectively. ${ }^{9}$ All the surviving wills dating from between 1440 and 1579 registered in the three local ecclesiastical probate courts, 234 wills in total, were studied. ${ }^{10}$ After setting the scene, looking at the number of women tenants and the degree of women's participation in the land market in Section I, the essay follows women's life-cycle of property possession. Section II considers daughters' inheritance, Section III married women's rights to land, and Section IV provisions for widows in men's wills. Section V examines what widows actually did after their husbands' death, looking in particular at widows' remarriage. The Conclusion draws together the findings, suggesting four dominant factors that determined women's access to land.

\section{WOMEN AS TENANTS AND PARTICIPANTS IN THE LAND MARKET}

The pattern of female tenancy in four north-east Norfolk manors is shown in Table 1. The percentage of female tenants and the amount of land they held varied from manor to manor, but we can make some generalizations. All the manors had female tenants, but female tenants rarely made up more than 10 per cent of landholders on any one manor. Other listings from Hevingham Bishops demonstrate that, in that manor at least, the proportion of female tenants was quite stable during the first half of the sixteenth century, making up 13 per cent of tenants in 1509,10 per cent in c.1515, and 10 per cent in $1540 .{ }^{11}$ The proportion of land held by women varied between the manors from 2.6 per cent to 16.6 per cent. Where the information was available, in Hevingham Bishops manor and Lord Morley's lands, all the female tenants were widows. The landholding pattern in this region of Norfolk was quite strongly polarized: typically manors contained a few large and medium-sized tenants and a multitude of smallholders. The pattern of landholding by women was very similar. There were a few large tenants, such as Audry Stubbs and Joan Stalon, who each held parts of sub-manors from the Lord Morley, and thus were manorial lords themselves. Two female tenants in Saxthorpe Mickelhall, 
TABLE 1

Female tenants in four north-east Norfolk manors

\begin{tabular}{|c|c|c|c|c|c|c|}
\hline & $\begin{array}{c}\text { Total } \\
\text { tenants } \\
\quad(n)\end{array}$ & $\begin{array}{c}\text { Female } \\
\text { tenants } \\
(n)\end{array}$ & $\begin{array}{c}\text { Female } \\
\text { tenants } \\
(\%)\end{array}$ & $\begin{array}{c}\text { Total } \\
\text { area } \\
\text { (acres) }\end{array}$ & $\begin{array}{c}\text { Area } \\
\text { held by } \\
\text { women } \\
\text { (acres) }\end{array}$ & $\begin{array}{c}\text { Area } \\
\text { held by } \\
\text { women } \\
(\%)\end{array}$ \\
\hline Hevingham Bishops c. 1515 & 49 & 5 & 10.2 & 566.00 & 26.50 & 4.7 \\
\hline Hevingham Cattes c. 1500 & 28 & 2 & 7.1 & 42.25 & 1.10 & 2.6 \\
\hline Lord Morley's lands 1529 & 83 & 8 & 9.6 & 1161.31 & 180.53 & 15.5 \\
\hline Saxthorpe Mickelhall 1500 & 41 & 2 & 4.9 & 294.25 & 48.88 & 16.6 \\
\hline Total & 201 & 17 & 8.4 & 2063.81 & 257.01 & 12.4 \\
\hline
\end{tabular}

Sources: Norfolk and Norwich Record Office, Norwich: NRS 13714 28D6, undated extent, Hevingham; NRS 14479 29C1, undated extent, probably incomplete, Hevingham Cattes; rental of Henry Parker knight, Lord Morley 1529, Castle Museum Deposit 20:8:59 (sheet T150D), sections relating to Buxton, Stratton, Hevingham, Marsham and Brampton; NRS 19709 42E6, rental of 1500, Saxthorpe Mickelhall.

and one in Hevingham Bishops, were medium-sized landholders with between 20 and 30 acres each. The other women were all smallholders with 5 acres or less. The median amount of land held by the women was 1.75 acres. So the pattern of women's landholding was similar to that of men's: women existed as minor manorial lords, middle-sized tenants and smallholders. Smallholders dominated, but this was also true of male landholders. The difference lies in the number of female tenants: on average only one tenant in twelve was female.

Campbell's study of Coltishall, a few miles to the south-east of Hevingham, suggests that the proportion of female tenants may have been higher in the fourteenth century. His figures show that in 1314, and in 1349 just after the first outbreak of plague, 18 per cent of tenants were women. This percentage dropped to 7 per cent in 1359 and 9 per cent in 1370, before rising to an unprecedented level of 29 per cent in 1406 . Campbell, however, notes that the lists of tenants from which these figures are derived may not all have been complete. In her study of pre-plague Brigstock of Northamptonshire, Bennett found that the same percentage, 18 per cent, of tenants were female in 1319. She estimates that one in five was a typical incidence of female tenants in Brigstock in the first half of the fourteenth century. Again, Franklin found that a similar figure, 17 per cent, of tenants whose death was recorded in the court rolls of Thornbury, Gloucestershire, in the years 1328-1348 were women. Russell looked at 40 manorial extents dating from between 1258 and 1358, from all over England, and found that 15 per cent of tenants were women. If we exclude 
free tenants, the proportion is 17 per cent. Titow found lower proportions: in a selection of 13 manors from southern and western England, the proportion of female tenants was only 12 per cent. He notes considerable variation, however, from a very low 6.4 per cent in Taunton to a high 21.6 per cent in Bishopstone. ${ }^{12}$ These figures demonstrate that while there was variation from manor to manor and over time, a proportion of between 12 and 18 per cent was the norm in the years before the Black Death. Female landholders made up a higher proportion of tenants in medieval England than they did in the early-sixteenth-century north-east Norfolk manors shown in Table 1.

Comparative figures for the early modern period are more difficult to come by. Davenport, Oestmann and Spufford in their respective studies give lists of tenants' names for particular manors, which allow the proportion of women tenants to be calculated. In Forncett, south Norfolk, in 1565, 11 per cent of the 163 named tenants were women. In Hunstanton, north-west Norfolk, in 1537-1538, out of 41 tenants none were widows and only 2 were women, whose husbands held in their right. In 1559 there were again only 2 female tenants out of a total of 40 . Unfortunately Oestmann makes no comment about the striking absence of widowed women among the tenants of this manor, nor about the low overall proportion of female tenants. Spufford's lists relating to two Cambridgeshire villages also demonstrate low proportions of female tenants in the sixteenth and early seventeenth centuries: 7 per cent in Chippenham in 1560, 4 per cent in Willingham in 1575 and 7 per cent in Willingham in 1603 . In the 1720 s, however, the proportion of women tenants in the smallholding, fen-edge village of Willingham was much higher, at least 18 per cent, while in Chippenham by 1712 there were no female tenants. Further afield, Todd found that widows made up 20 per cent of tenants in Long Wittenham in Berkshire in 1659, and notes that a similar proportion of 21 per cent was found for the manor of Mardon in Hursley, Hampshire, in 1707, while Seeliger states that 'women formed up to one fifth of all tenants on most manors at any time before about 1850 in Hampshire' ${ }^{13}$ This diverse set of figures does not lead us to any firm conclusions. It is possible that the proportion of female tenants declined over time in eastern England, but remained stable or even increased in the southern and midland England. However, other commentators have assumed that, as traditional copyhold tenures were eroded in favour of leasehold, widows' access to land decreased all over England.${ }^{14}$ Willingham is unusual in having experienced an increase in the number of female tenants over the early modern period. Interestingly, it also saw an increase in the number of small landholders in the late seventeenth and eighteenth centuries, the opposite of the national trend. 
TABLE 2

Acquisition of land recorded in the court rolls of Hevingham Bishops manor, 1444-1558

\begin{tabular}{|c|c|c|c|c|c|c|c|c|}
\hline & \multicolumn{2}{|c|}{$1444-1460(n)$} & \multicolumn{2}{|c|}{$1547-1558(n)$} & \multicolumn{2}{|c|}{$1444-1460(\%)$} & \multicolumn{2}{|c|}{$1547-1558(\%)$} \\
\hline & Male & Female & Male & Female & Male & Female & Male & Female \\
\hline As a married couple & 44 & 44 & 12 & 12 & 23.6 & 75.9 & 12.4 & 52.2 \\
\hline As a sole person & 105 & 5 & 61 & 9 & 56.4 & 8.6 & 62.9 & 39.1 \\
\hline With other relatives & 2 & 7 & 5 & 2 & 1.1 & 12.1 & 5.2 & 8.7 \\
\hline With unrelated men & 32 & 0 & 19 & 0 & 17.2 & 0.0 & 19.6 & 0.0 \\
\hline Other types of group & 3 & 2 & 0 & 0 & 1.6 & 3.4 & 0.0 & 0.0 \\
\hline Total & 186 & 58 & 97 & 23 & 99.9 & 100.0 & 100.1 & 100.0 \\
\hline From a relation & 13 & 13 & 36 & 13 & 7.0 & 22.4 & 37.1 & 56.5 \\
\hline
\end{tabular}

Source: Hevingham Court Rolls, Norfolk and Norwich Record Office, Norwich (see note 7).

Surveys and rentals provide snapshots of women's access to land. To gain a broader picture, and to understand why women only made up around 10 per cent of tenants in the north-east Norfolk manors studied here, it is necessary to examine women's participation in the land market through the transfers of land recorded in court rolls. While women made up 10-13 per cent of tenants in Hevingham Bishops between 1509 and 1540 , in the mid fifteenth century 24 per cent of people receiving land in transactions recorded in the court rolls were women, and in the mid sixteenth century 19 per cent were. This higher rate of participation is expained by the fact that women usually received land jointly, as part of a married couple or with other relatives. When women received land jointly with men, it was very rare for them to be recorded as the primary tenant, the person whose name is recorded as tenant in manorial surveys and other lists of tenants. Table 2 contrasts male and female patterns of land acquisition, comparing the mid fifteenth century with the mid sixteenth. While there are clearly differences in land market activity between the two periods, with a general decline in activity and an increase in the proportion of land transfers within the family, the difference between male and female activity is quite constant over time. Two main differences stand out. First, while the majority of men received land solely, as the only tenant, women typically received land as joint tenants, normally as part of a married couple. Second, women were much more likely than men to receive the land from a relative. So while women can hardly be described as absent from the manorial land market, their 
pattern of participation was very different from that of men. Unlike the men of this part of Norfolk, women did not buy and sell pieces of land actively during the course of their lifetime, they did not often act alone and they were less likely to purchase land from outside the family. When all the surviving court rolls from the period 1444-1558 were searched, only eight cases of women receiving land alone and from a non-relative were found. ${ }^{15}$ None of these women received land in this way more than once, and the largest holding was five acres in size. All the women were widows. They appear either to have been finishing a transfer arranged by their deceased husband, or to be setting themselves up with a retirement home. Both the manorial surveys and the general pattern of land transfer suggest that women rarely held land independently before widowhood.

Bennett found a very similar pattern of female participation in the land market in pre-plague Brigstock. ${ }^{16}$ In her examination of the participants in land transfers she found that 'only about one in five was a woman'. Additionally she notes that while only one in eight men granted or received land jointly, three out of eight women did so, and that women were twice as likely as men to be involved in intra-family land transfers. Only the activities of daughters present a strong contrast between Hevingham and Brigstock. Unmarried women other than widows appeared extremely rarely in Hevingham's court rolls between 1444 and 1558. Most commonly they appeared inheriting land, but this was itself quite unusual, as is discussed below. In contrast it was not unusual for young women in early-fourteenth-century Brigstock to acquire land before marriage, and not only from other family members. This difference cannot be explained in terms of inheritance custom, which was roughly the same in Hevingham and Brigstock, with daughters inheriting jointly if there were no sons. Seeliger's study of surrenders and admissions to landholdings in six Hampshire manors between 1567 and 1852 reveals rates of women's participation similar to those in Hevingham, of between 15 and 24 per cent. However, as she counts transfers to and from married couples as transfers by women and not men, 'since in these cases the land was often held in right of the wife', it is unclear whether they are strictly comparable. ${ }^{17}$ Todd notes that, in Long Wittenham, widows simply enjoyed their secure freebench and did not take up opportunities to purchase land. This stood in contrast to nearby Sutton Courtney, where widows had no customary rights to their husband's land, and wealthy widows are observed purchasing land, as well as lending money in an active credit market. ${ }^{18}$ It seems that while there are geographical variations, there are also some strong continuities in women's participation in the land market over time, with women being more likely to receive land from relatives and as joint tenants than men, and less active 
TABLE 3

Instances of customary inheritance in Hevingham Bishops, 1444-1558

\begin{tabular}{lcc}
\hline \hline & Heirs $(n)$ & Heirs $(\%)$ \\
\hline To one son & 37 & 64.9 \\
To other male $^{a}$ & 3 & 5.3 \\
To sole daughter & 3 & 5.3 \\
To 2 daughters jointly & 10 & 17.5 \\
To 3 daughters jointly & 3 & 5.3 \\
To other female $^{c}$ & 1 & 1.8 \\
Total & 57 & 100.1 \\
\hline \hline
\end{tabular}

${ }^{a}$ Two cases of inheritance from man to grandson; one case from man to nephew.

${ }^{b}$ The number of individual heirs is given. Thus there were five cases of two daughters inheriting jointly (ten individuals), one of three daughters inheriting jointly, and three of lone daughters inheriting.

${ }^{c}$ One case from man to great-granddaughter.

Source: Hevingham court rolls, Norfolk and Norwich Record Office, Norwich (see note 7).

in their general participation in land exchange activities. The limited evidence available, from medieval Brigstock and sixteenth-century Hevingham, suggests that one possible contrast between the medieval period and the sixteenth century was in young single women's acquisition of land.

\section{INHERITANCE BY DAUGHTERS}

The active land market in north-east Norfolk meant that parents had a choice in passing land to their children: they could either make no special arrangements, and the land would pass according to custom to the nearest heir, or they could transfer the land before death or make a will specifying who should receive the land, or whether the land was to be sold and its cash value divided. The inheritance custom of Hevingham Bishops manor was that the land went to one son. ${ }^{19}$ If there were no sons, daughters inherited jointly. There was no clear right of widow's dower. Therefore, if a man or woman died without making other arrangements, land would pass directly to a son if he or she had a son, or jointly to daughters if there were no sons. Table 3 shows the pattern of customary inheritance actually observed in Hevingham's court rolls between 1444 and 1558. There were 50 instances of the customary inheritance in which, as a result of daughters inheriting jointly, a total of 57 people inherited land. So while the majority of inheritors were sons, 30 per cent of heirs were daughters 
TABLE 4

Bequests of land in men's and women's wills in six Norfolk parishes, $1440-1579$

\begin{tabular}{lrrrrr}
\hline \hline & \multicolumn{2}{c}{ Bequests $(n)$} & & \multicolumn{2}{c}{ Bequests $(\%)$} \\
\cline { 2 - 3 } \cline { 5 - 6 } & By men & By women & & By men & By women \\
\hline To widow & 80 & - & & 36 & - \\
To son & 69 & 8 & & 31 & 28 \\
To son-in-law & 4 & 2 & & 2 & 7 \\
To other male relatives & 9 & 5 & & 4 & 17 \\
To unrelated man ${ }^{a}$ & 10 & 2 & & 4 & 7 \\
To daughter & 6 & 3 & & 3 & 10 \\
To other female relatives & 4 & 0 & & 2 & 0 \\
To unrelated woman & 3 & 1 & & 1 & 3 \\
Total to women & 93 & 4 & & 42 & 14 \\
Total to men & 92 & 17 & & 41 & 59 \\
Land to be sold (to anyone) & $b 9$ & 8 & & 17 & 28 \\
Total bequests & 224 & 29 & & 100 & 101 \\
Total number of wills & 137 & 19 & & - & - \\
\hline \hline
\end{tabular}

a People were assumed to be unrelated when no relationships was stated and they did not share a surname.

${ }^{b}$ Sales to named people were counted as bequests and excluded from this category.

Source: Wills of probate courts (Norwich Consistory Court, Norwich Archdeaconry Court and Norfolk Archdeaconry Court), Norfolk and Norwich Record Office, Norwich, for the parishes of Marsham, Hevingham, Brampton, Corpusty, Saxthorpe and Scottow.

or other female relatives. We should remember that because the land was split between daughters, the daughters who did inherit were likely to receive less than a male heir. Nevertheless, despite the inheritance custom giving preference to male heirs, the number of female heirs is not insignificant.

However, the low incidence of customary inheritance in the court rolls of this part of Norfolk demonstrates that the majority of children did not acquire land by this route. Other types of land transfers in which the parent had an active choice, such as deathbed surrenders, joint tenure between parent and child and inter-vivos transfers from parent to child, could be used by parents to give land to their children. Hevingham's surviving court rolls from 1444-1558 reveal that means such as these were used 31 times to transfer land to sons. Daughters received land by these means on only 4 occasions. ${ }^{20}$ Wills provide important evidence of actual inheritance strategies, recording as they do the bequests given to sons and daughters who did not receive land, as well as those who did. Table 4 
compares men's and women's wills, taking evidence from the 156 wills from the six parishes that mentioned land. These 156 wills included 253 bequests of land, indicating that landholdings were frequently split, either literally or over time, being bequeathed first to one person and then another, for instance to the widow and after her death to a son. If we concentrate first on the men's wills, and compare the pattern of land devolution found in wills with that resulting from customary inheritance, there are two main differences. First, while customary inheritance gave nothing to widows, in wills widows frequently received bequests of land: over a third of all bequests of land were to widows. Second, a significant proportion of land was devolved outside the family, to be sold to some unspecified person or to a non-relative, in order to raise money to pay for other bequests. Over 20 per cent of men's bequests of land fell into these categories. Sons made up only 31 per cent of land-inheritors in wills compared to 65 per cent of customary heirs, while daughters made up 3 per cent rather than 28 per cent. Even if we assume that some apparently unrelated women were actually married daughters, and regard bequests to sons-in-law as bequests to daughters, daughters received only 6 per cent of all bequests of land found in men's wills. It appears that wills were used to spread bequests of land more widely, and as a result both sons and daughters were less likely to inherit their father's land than in the customary system. Only a tiny proportion of daughters received land. While sons also lost out, male patterns of participation in the land market demonstrate that sons took alternative routes to acquiring land. A son who was not bequeathed land might use his cash bequest or earnings to purchase a landholding, and we frequently see men acquiring their first landholding from a non-relative. Daughters did not generally take this route to acquire land before marriage.

The proportion of daughters who were left land in their father's will is particularly low in this collection of wills. Only 3.6 per cent of men who bequeathed land left it to daughters, or 6.5 per cent if bequests to sons-inlaw are included. Studies of wills by Evans and Erickson indicate higher proportion of daughters receiving land. ${ }^{21}$ In both studies, only the proportion of daughters with brothers is given. Evans found that in Fressingfield and Laxfield in Suffolk between 1372 and 1540, 2 per cent of wills bequeathed land to daughters whose brothers were also left land, while for Bungay, Suffolk between 1550 and 1600, the equivalent figure was 7 per cent. Erickson found that in Sussex and Lincolnshire between 1579 and 1689,5 per cent of men with sons gave bequests of land to daughters, while the proportion was much higher at 26 per cent in rural Yorkshire in 1640-1690. We can assume that daughters with no brothers were even more likely to be given land. Spufford notes that 'it was not 
common for women to inherit land' in the three Cambridgeshire villages she studied, but that they did so when there 'was no son, or occasionally at the whim of an eccentric father, or even grandmother'. ${ }^{22}$ Erickson asserts that men preferred to leave land to lineal females rather than collateral males: 'When a man had daughters but no sons he generally gave his land to his daughters, rather than to his brothers, nephews or even grandsons' ${ }^{23}$ In north-east Norfolk this was not the case. The number of bequests of land to brothers, nephews and grandsons equalled those to daughters, while the number to male relatives more generally (other than sons), who received land was slightly greater. Both these categories were outnumbered by requests for land to be sold.

The reluctance to bequeath land to daughters in fifteenth- and sixteenthcentury north-east Norfolk was not only a male phenomenon. Table 4 demonstrates that 10 per cent of bequests of land by women went to daughters, in comparison to 3 per cent made by men. This difference is not great when other factors are taken into consideration. First, the number of wills is very small: out of the 44 wills made by women, only 19 included bequests of land. Second, to state the obvious, women's bequests of land differed from men's in that they had no widow to provide for. Male and female will-makers left a similar proportion of bequests of land to sons. The equivalent of the 36 per cent of bequests that men made to widows was spread by female will-makers between male relatives other than sons, daughters and requests for the land to be sold. Women were even keener than men to bequeath land to more distant male relatives, or to sell it outside the family, rather than give it to their daughters. In her study of Norfolk wills in 1590-1750, Amussen found that 30 per cent of women with more than one child left land to one daughter, in comparison to 6.7 per cent of men, from which she concludes that 'Women offered a subtle critique of the patriarchal assumptions of the period by giving more authority and power to their daughters than their husbands did ' ${ }^{24} \mathrm{We}$ cannot uphold this conclusion; as Table 4 demonstrates, while women were slightly more likely to make bequests of land to daughters than were men, men were in fact much more likely to make bequests of land to women generally, because they left land to their widows.

The fact that daughters rarely received land in this part of Norfolk does not mean that they received nothing by way of inheritance. Cash was the most common type of bequest. ${ }^{25}$ In 86 per cent of men's wills that mentioned daughters, daughters received cash bequests and not land. Smith notes that the trend of daughters failing to inherit land in accordance with the opportunities theoretically available to them' and receiving a cash gift instead was already evident in the period 1370-1430 in a selection of seven manors from the Home Counties and East Anglia. ${ }^{26}$ 
A preference for cash bequests rather than bequests of goods is observed by Evans in the wills of Fressingfield and Laxfield in 1372-1540 and in Bungay $1550-1600$, and by Alan Macfarlane with regard to Earls Colne in Essex, while Erickson assumes that daughters most commonly received moveable goods as their main inheritance. ${ }^{27}$ The overall situation in Norfolk, if we take into account not only the daughters of men who died intestate, who probably received moveables, but also the fact many daughters received their 'inheritance' at marriage, and therefore probably received cash, is inconclusive.

In Women and property, Erickson challenges the assumption that simply because daughters tended to receive moveable goods and not land, they received bequests of lesser value. She argues that 'the cash values of land and moveables were relatively close in the early modern period'; thus while daughters received a different type of bequest, they did not necessarily receive less. ${ }^{28}$ As the purchase price of land sold between tenants is recorded in Hevingham's court rolls, a direct comparison between the local price of land and the size of cash bequests received by both sons and daughters who did not receive land could be made, and is shown in Table 5. Two time periods are compared because the price of land increased rapidly after around 1530, partly as a result of inflation. Two different land prices are also provided. One is the average price per acre and the other is the average price per acre for landholdings less than four acres in size. For reasons that are not entirely clear, but can be guessed at, the price per acre for smallholdings was considerably higher than that for medium- and large-sized landholdings. ${ }^{29}$ As most cash bequests would have only allowed the recipient to buy a few acres, the average price per acre for smallholdings is perhaps more relevant. These findings are based on a small number of examples, both of priced land transactions and cash bequests, and thus should be treated warily. Nevertheless they indicate some interesting patterns. First, the mean cash bequest was considerably higher than the median, so most children did not receive as much as the mean amount. Second, when sons and daughters are compared, there is no clear pattern of sons being favoured over daughters or vice versa. When all the wills dating from 1440 to 1579 are examined this picture is one of approximate equality. For the whole period the mean cash bequest received by sons who did not receive land was $£ 514 \mathrm{~s} 9 \mathrm{~d}$, compared to $£ 510 \mathrm{~s} 3 \mathrm{~d}$ received by daughters. Third, the mean cash bequests more or less kept pace with inflated land prices in the later period, but median cash bequests did not. Fourth, it is clear that a cash bequest of mean size would allow a couple who had not been bequeathed land to purchase a smallholding of a few acres. However, those who received the median cash bequest or less would have struggled 
TABLE 5

Cash bequests in the wills of six Norfolk parishes and the price of land in Hevingham Bishops manor, 1498-1558

\begin{tabular}{|c|c|c|c|c|c|}
\hline \multicolumn{6}{|c|}{ (a) $1498-1528^{a}$} \\
\hline & $\begin{array}{l}\text { Size of } \\
\text { cash } \\
\text { bequest }^{b}\end{array}$ & $\begin{array}{l}\text { Price of } \\
\text { land per } \\
\text { acre }(1)^{c}\end{array}$ & $\begin{array}{l}\text { Acreage } \\
\text { that could } \\
\text { be bought }\end{array}$ & $\begin{array}{l}\text { Price of } \\
\text { land per } \\
\text { acre }(2)^{d}\end{array}$ & $\begin{array}{l}\text { Acreage } \\
\text { that could } \\
\text { be bought }\end{array}$ \\
\hline $\begin{array}{l}\text { Mean cash bequest for } \\
\text { daughter }\end{array}$ & $£ 213 \mathrm{~s} 4 \mathrm{~d}$ & $£ 16 \mathrm{~s} 5 \mathrm{~d}$ & 2.02 acres & $£ 3$ 15s 1d & 0.71 acres \\
\hline $\begin{array}{l}\text { Mean cash bequest for } \\
\text { son }\end{array}$ & $£ 2$ os $10 \mathrm{~d}$ & $£ 16 \mathrm{~s} 5 \mathrm{~d}$ & 1.55 acres & $£ 315 \mathrm{~s} 1 \mathrm{~d}$ & 0.54 acres \\
\hline $\begin{array}{l}\text { Median cash bequest for } \\
\text { daughter }\end{array}$ & $16 \mathrm{~s} 8 \mathrm{~d}$ & $£ 16 \mathrm{~s} 5 \mathrm{~d}$ & 0.63 acres & $£ 315$ s $1 \mathrm{~d}$ & 0.22 acres \\
\hline $\begin{array}{l}\text { Median cash bequest for } \\
\text { son }\end{array}$ & $£ 13 \mathrm{~s} 0 \mathrm{~d}$ & $£ 16 \mathrm{~s} 5 \mathrm{~d}$ & 0.87 acres & $£ 315$ s $1 \mathrm{~d}$ & 0.31 acres \\
\hline \multicolumn{6}{|c|}{ (b) $1529-1558^{e}$} \\
\hline & $\begin{array}{l}\text { Size of } \\
\text { cash } \\
\text { bequest }\end{array}$ & $\begin{array}{l}\text { Price of } \\
\text { land per } \\
\text { acre }(1)\end{array}$ & $\begin{array}{l}\text { Acreage } \\
\text { that could } \\
\text { be bought }\end{array}$ & $\begin{array}{l}\text { Price of } \\
\text { land per } \\
\text { acre (2) }\end{array}$ & $\begin{array}{l}\text { Acreage } \\
\text { that could } \\
\text { be bought }\end{array}$ \\
\hline $\begin{array}{l}\text { Mean cash bequest for } \\
\text { daughter }\end{array}$ & $£ 57 \mathrm{~s} 2 \mathrm{~d}$ & $£ 319 \mathrm{~s} 7 \mathrm{~d}$ & 1.34 acres & $£ 710 \mathrm{~s} 0 \mathrm{~d}$ & 0.71 acres \\
\hline $\begin{array}{l}\text { Mean cash bequest for } \\
\text { son }\end{array}$ & $£ 6$ 18s 2d & $£ 319 \mathrm{~s} 7 \mathrm{~d}$ & 1.74 acres & $£ 710 \mathrm{~s} 0 \mathrm{~d}$ & 0.92 acres \\
\hline $\begin{array}{l}\text { Median cash bequest for } \\
\text { daughter }\end{array}$ & $£ 16 \mathrm{~s} 8 \mathrm{~d}$ & $£ 319 \mathrm{~s} 7 \mathrm{~d}$ & 0.33 acres & $£ 710$ s $0 \mathrm{~d}$ & 0.18 acres \\
\hline $\begin{array}{l}\text { Median cash bequest for } \\
\text { son }\end{array}$ & $£ 10$ s $0 \mathrm{~d}$ & $£ 319 \mathrm{~s} 7 \mathrm{~d}$ & 0.25 acres & $£ 710$ s $0 \mathrm{~d}$ & 0.13 acres \\
\hline
\end{tabular}

${ }^{a}$ Land prices were taken from 52 payment agreements, 26 of which were under four acres in size. The daughters' cash bequests were taken from 23 wills and the sons' cash bequests from 27 wills.

${ }^{b}$ Only cash bequests to sons and daughters who did not receive land.

${ }^{c}$ Average price per acre.

${ }^{d}$ Average price per acre for landholdings less than four acres in size.

${ }^{e}$ Land prices were taken from 34 payment agreements, 27 of which were holdings under four acres in size. The daughters' cash bequests were taken from 31 wills and the sons' cash bequests from 19 wills.

Sources: Hevingham court rolls and wills of probate courts (as detailed in note to Table 4), Norfolk and Norwich Record Office, Norwich.

to purchase anything more than a cottage with a garden, particularly in the later period.

But were such bequests equivalent to the bequests of land given to one or more sons in the same wills? Many sons and daughters who received 
cash bequests came from families where no land was bequeathed and thus were treated with rough equality. However when a son was bequeathed land it was generally more than the average cash bequest could purchase. To complicate matters further, this apparent inequality was often ironed out by requiring the land-inheriting son to pay for the land, providing the cash for his siblings' bequests. ${ }^{30}$ Such wills demonstrate the inequality of the division elsewhere. For instance, in 1537 Peter Robardes of Saxthorpe bequeathed to his son Thomas all his houses and lands at the age of 22, if he paid $£ 1413 \mathrm{~s} 4 \mathrm{~d}$ for them. He then gave all of his four children (two sons and two daughters, including Thomas) equal bequests of $6 \mathrm{~s} 8 \mathrm{~d}$, a cow and two sheep. In Scottow in 1548 John Becker acted similarly, giving his sons Harry and John houses and lands for which they each had to pay £34. His daughter Margaret was given $£ 3$ 6s $8 \mathrm{~d}$ and nothing else. These wills illustrate the difference in value between bequests of houses and land and bequests of cash only. The real property was almost always worth considerably more. In addition, we should note that while goods depreciated over time and cash had to be invested to maintain or improve its value, land and houses gained value largely irrespective of their management, as well as possessing the potential for income generation through farming or subletting. Daughters rarely received real property, but sons quite often did, and this was a real inequality. However, this inequality was mitigated. Some sons had to pay for the land they received from parents, and many sons were not bequeathed land. Cash bequests could be used to purchase smallholdings. Thus our data uphold Erickson's more general point about a rough equality in the treatment of most sons and daughters, but do not demonstrate equality between bequests of real property and bequests of other types of property.

A final aspect of daughters' inheritance that must be taken into account is timing. Daughters tended to received their inheritance at marriage, while sons generally received it at their father's death, if they were old enough. Assuming that landholders produced sons and daughters with equal frequency, we find that daughters are under-recorded in wills by 26 per cent. It is very likely that the shortfall in daughters occurs because they received their inheritance at marriage before the will was made. The common assumption that daughters should receive their inheritance at marriage is also demonstrated by wills with bequests to minor children, in which it was specified that daughters should receive their inheritance at marriage, a direction that was never stated in the case of sons. ${ }^{31}$ The fact that many daughters received their inheritance before their father's death may have contributed to the unwillingness to give them land. ${ }^{32}$ Land transfers in Hevingham Bishops demonstrate that sons very rarely received land from their father before his immanent death. In summary, 
daughters in north-east Norfolk in the period 1440 to 1580 rarely received an inheritance of land. This stands in contrast to both the century before the Black Death and other regions of early modern England, where daughters with no brothers received land as a matter of course, and a small but significant proportion of daughters with brothers also received land. Instead daughters were commonly given bequests of cash. In northeast Norfolk, larger cash bequests could be used to purchase small cottage properties, but they were of lesser value than the types of landholdings that many sons received from their parents.

\section{MARRIED WOMEN AND LANDHOLDING}

Marriage was a significant event in a woman's property-holding career. Women often received their inheritance at marriage, and frequently became landholders for the first time. Men were more likely to have acquired land before marriage and the act of marriage did little to alter their property rights. We can assume that the woman's inheritance and saved earnings were used by the couple in the joint acquisition of land. But ironically, or perhaps logically in sixteenth-century thinking, a woman lost the right on marriage to own property in her own right, because of coverture, precisely at this time. Coverture affected women's rights to moveable goods, freehold land and customary land differently. Its complexities have been described elsewhere and will not be examined here. ${ }^{33}$ Instead, this section explores the realities of married women's access to property, and in particular, their rights to customary land.

Married women in north-east Norfolk commonly held land by joint tenure with their husband. As we have seen, never-married women rarely held land before marriage, although it was more common for remarrying widows to do so. Women who had no land when they married, if they were to be given rights to land, either purchased land jointly with their husband or received land from their husband as a regrant to joint tenure. When widows with land remarried the land could either be held by the husband 'in right of his wife' for the duration of the marriage or, more commonly, the woman could regrant her land to joint tenure with her new husband. To quantify the extent of joint tenure between married couples, the landholdings histories of all men who served on Hevingham's manorial jury between 1485 and 1546 - which in effect means the great majority of resident non-gentry male tenants - were examined. There were 106 such men in total. Two men, one of whom was single and one whose landholding history is unclear, were excluded. Of the remaining 104 men, 
26.5 per cent held all their land jointly with their wife, 40.8 per cent held some but not all their land jointly, while 32.6 per cent of men held no land jointly with their wife.

Joint tenure gave the wife, and her husband, quite definite rights to land. A married woman's rights in land which she held as joint tenant were no different from those of a man holding jointly with other men. The woman's husband could not sell or otherwise alienate that land without her permission. Entries in the court roll describing the surrender of land held jointly by married couples record the formal procedure of the wife being examined separately by the court steward as to whether she gave her consent to the transaction. ${ }^{34}$ The emergence of this procedure in the court rolls of late thirteenth and early fourteenth centuries has been documented by Smith. ${ }^{35}$ While the separate examination of the wife appears to be an example of the manorial court respecting women's rights to property, we should be wary of such an assumption. The most obvious function of the process, and perhaps the main reason for its development, was to protect the property rights of the person who acquired the land from the couple, by preventing the woman from claiming rights to that land when she entered widowhood ${ }^{36}$ There are no records of a woman refusing her consent when examined separately in the court rolls studied. We can suppose that this indicates either that husband and wife always acted in perfect harmony, or that in reality the wife had little choice but to acquiesce in her husband's actions. ${ }^{37}$

Whatever the advantages or disadvantages of joint tenure during marriage, joint tenure conferred clear and certain rights in the event of the husband's death. Right in the land devolved to the woman, as the surviving tenant, without the payment of a fine. Couples held land by joint tenure in Hevingham because if they did not do so the wife's rights to her husband's land - which we can assume she worked on, managed jointly with him and may have helped purchase - were virtually non-existent. There is no evidence of dower being awarded to women under normal circumstances, or of married men being restricted in their sale of land when the wife was not recorded overtly as joint tenant. This is in sharp contrast to manors in other parts of England at this time, where widows were conferred rights of freebench in all or at least a third of their husband's land, with rights applying to all land held by the husband during the marriage. Given the situation in Hevingham, perhaps the more pertinent question is why nearly a third of men did not hold land jointly with their wives. There is no clear correlation with the size of the landholding: large landholders were neither more nor less likely to hold land jointly than smallholders. It is likely, instead, that the variation relates to the amount of wealth a woman brought into the marriage. If she 
or her natal family contributed significantly to the purchase of land, then it was held jointly; if not, then it was not, but this cannot be proved.

Finally, it should be noted that the possession of joint tenure did not necessarily determine the manner in which a widow was provided for after her husband's death. Two contrasting histories from early-sixteenthcentury Marsham, those of Robert and Alice Bisshop and of John and Maud Wake, illustrate this. Robert Bisshop and his wife Alice always held their main holding of over 30 acres jointly. They were childless, and when Robert died in 1500 Alice immediately surrendered the holding to Robert's nephew and namesake. However, she required Robert junior to pay her $£ 2613 \mathrm{~s} 4 \mathrm{~d}$ and provide her with a place to live and other necessities for the rest of her life. Conversely, John Wake's wife Maud never held land jointly with him, but he surrendered his whole holding to her on his deathbed in 1503, rather than to any of their three sons. In his will John bequeathed Maud the land to give and sell, with the only condition that, if she sold it, she offered it first to their son Nicholas.

\section{PROVISION FOR WIDOWS IN MEN'S WILLS}

It was as widows that women most commonly became independent landholders. While daughters and married women rarely held or managed landed property on their own, the situation with regard to widows was very different. Wills allow us to study the treatment of widows in some detail, and it is the aspect of women's landholding that has previously received most attention in studies of the sixteenth and seventeenth centuries. The relative plethora of information on widows in men's wills should be treated carefully. We are not viewing the male will-maker's generosity, but rather his power to divide the jointly held and generated marital property between his partner (the wife), their offspring, and any others he chose to favour. ${ }^{38}$ It should also be remembered that while sons, and to a certain extent daughters, could find work, for instance as servants, and generate their own income, a widow's options were more restricted. To live independently or to remarry, she needed to be left some of the fruits of her marital household economy.

The appointment of a widow as the executrix of her husband's will implies both that the widow received some or all of the 'residue' (the items not specifically bequeathed in the will), if there was any, and that her husband thought her capable of managing his estate. ${ }^{39}$ However, just as patterns of customary inheritance were more favourable to daughters' inheritance of land than the bequests they received in wills, we should note that if a man did not make a will - and the majority did not - the widow was more likely to administer his estate than if he did. A widow was legally 
TABLE 6

The appointment of widows as executrix, in wills of men with widows in six Norfolk parishes, 1440-1579 ${ }^{a}$

\begin{tabular}{|c|c|c|c|c|c|c|c|c|c|}
\hline & \multicolumn{2}{|c|}{$\begin{array}{c}\text { Sole executrix, } \\
\text { no supervisor }\end{array}$} & \multicolumn{2}{|c|}{$\begin{array}{l}\text { Sole executrix, } \\
\text { with supervisor }\end{array}$} & \multicolumn{2}{|c|}{ Joint executor } & \multicolumn{2}{|c|}{$\begin{array}{l}\text { Widow not } \\
\text { executrix }\end{array}$} & \multirow{2}{*}{$\begin{array}{c}\text { Tota } \\
n\end{array}$} \\
\hline & $n$ & $\%$ & $n$ & $\%$ & $n$ & $\%$ & $n$ & $\%$ & \\
\hline $1440-1579$ & 35 & 25 & 20 & 14 & 44 & 32 & 39 & 28 & 138 \\
\hline $1440-1499$ & 1 & 5 & 0 & 0 & 15 & 71 & 5 & 24 & 21 \\
\hline $1500-1539$ & 20 & 32 & 5 & 8 & 19 & 31 & 18 & 29 & 62 \\
\hline $1540-1579$ & 14 & 25 & 15 & 27 & 10 & 18 & 16 & 29 & 55 \\
\hline 'Poor' $b$ & 30 & 39 & 9 & 12 & 25 & 32 & 13 & 17 & 77 \\
\hline 'Middling' & 3 & 9 & 6 & 17 & 12 & 34 & 14 & 40 & 35 \\
\hline 'Wealthy' & 2 & 8 & 5 & 19 & 7 & 27 & 12 & 46 & 26 \\
\hline With son $/ \mathrm{s}^{c}$ & 21 & 23 & 14 & 16 & 29 & 32 & 26 & 29 & 90 \\
\hline Without son & 14 & 29 & 6 & 13 & 15 & 31 & 13 & 27 & 48 \\
\hline
\end{tabular}

${ }^{a}$ Percentages calculated for wills in each row

${ }^{b}$ As inventories do not survive for Norfolk in this period in any significant number, and no other suitable sources were available, the only feasible method to obtain an indication of wealth was to add up the value of cash bequests in the wills. To allow for the effects of inflation, the period of study was split at 1530, with different wealth bands used to define the categories of 'poor', 'middling' and 'wealthy', before and after that date: pre-1530, poor $=<£ 5$, middling $=£ 5-£ 15$, wealthy $=>£ 15 ; 1530-1579$, poor $=<£ 10$, middling $=$ $£ 10-£ 25$, wealthy $=>£ 25$. Obviously, these descriptions of poverty and wealth are relative to this sample of wills, and for many reasons this is an extremely crude measure, and should be treated warily. However, the assumption has been made that it is accurate enough to be useful, providing a rough yardstick to compare the actions of will-makers of different levels of wealth.

${ }^{c}$ Wills in which one or more sons were mentioned.

Source: Wills of probate courts as detailed in note to Table 4.

entitled to administer her husband's estate on the occasion of his death, if he died intestate. ${ }^{40}$ The incidence with which widows were appointed executrix is shown in Table 6 . Of the 138 wills in which widows were mentioned and the executor's name is legible, the great majority, 72 per cent, appointed the widow as executrix in some form. This incidence is within the norm found by Erickson, who collated figures from various studies of wills from different parts of England, dating from between 1280 and $1710 .{ }^{41}$ A very similar rate, 73 per cent, of appointment of widows as executrices was found by Amussen in her study of Cawston, which neighbours on Hevingham and Marsham, for the period 1590-1750, although in Cawston the majority of women were appointed as sole executrix. ${ }^{42}$ In the six parishes studied here 'poor' will-makers were the most likely to appoint the widow as sole executrix, and as executrix in any 
TABLE 7

Bequests to widows in men's wills in six Norfolk parishes, 1440-1579a

\begin{tabular}{|c|c|c|c|c|c|c|c|c|c|}
\hline & \multicolumn{2}{|c|}{ Land plus ${ }^{b}$} & \multicolumn{2}{|c|}{$\begin{array}{c}\text { Dwelling and } \\
\text { maintenance } \\
\text { plus }^{b}\end{array}$} & \multicolumn{2}{|c|}{$\begin{array}{l}\text { Cash and } \\
\text { goods only }\end{array}$} & \multicolumn{2}{|c|}{ Goods only } & \multirow{2}{*}{$\begin{array}{c}\text { Total } \\
n\end{array}$} \\
\hline & $n$ & $\%$ & $n$ & $\%$ & $n$ & $\%$ & $n$ & $\%$ & \\
\hline $1440-1579$ & $79(112)^{c}$ & $57(71)$ & 15 & 11 & 13 & 9 & 32 & 23 & 139 \\
\hline $1440-1499$ & $12(15)$ & $55(80)$ & 2 & 9 & 2 & 9 & 6 & 27 & 22 \\
\hline $1500-1539$ & $39(53)$ & $63(74)$ & 5 & 8 & 6 & 10 & 12 & 19 & 62 \\
\hline $1540-1579$ & $28(44)$ & $51(64)$ & 8 & 15 & 5 & 9 & 14 & 25 & 55 \\
\hline 'Poor' ${ }^{\prime}$ & 47 & 61 & 3 & 4 & 1 & 1 & 26 & 34 & 77 \\
\hline 'Middling' & 16 & 47 & 5 & 15 & 9 & 26 & 4 & 12 & 34 \\
\hline 'Wealthy' & 16 & 57 & 7 & 25 & 3 & 11 & 2 & 7 & 28 \\
\hline With son/s & 56 & 62 & 11 & 12 & 9 & 10 & 15 & 16 & 91 \\
\hline Without son & 23 & 48 & 4 & 8 & 4 & 8 & 17 & 35 & 48 \\
\hline
\end{tabular}

a Percentages calculated for wills in each row

$b$ 'Land plus' means land plus anything else; 'Dwelling and maintenance plus' means dwelling and maintenance plus anything else except land (see text).

${ }^{c}$ Numbers in brackets show how many wills involving widows mentioned land at all; percentages in brackets show widows given land as a proportion of wills mentioning widows and land.

${ }^{d}$ For wealth definition see Table 6.

Source: Wills of probate courts as detailed in note to Table 4.

form, again a pattern that has been observed elsewhere. ${ }^{43}$ The low rate at which widows were appointed sole executrix in the fifteenth century may be a result of the higher proportion of wealthy will-makers in this period. The practice of appointing a male supervisor to help the widow execute the will became increasingly common as time passed, and correlates with a decline in the number of widows appointed as joint executors. The presence or absence of sons seems to have had relatively little influence on men's choice of executor. It cannot be assumed that all widows wished to be appointed as executrix. While it gave them economic freedom in dealing with their husband's affairs, it could be a troublesome duty and sometimes a financial burden, making them liable to pay their husband's debts.

The different bequests given to widows in wills are set out in Table 7 , divided into four broad categories: widows who received land, widows who received provision for their dwelling and maintenance but no land, widows who received cash and goods only and widows who received goods only. ${ }^{44}$ Widows who received land or dwelling and maintenance 
usually received goods and/or cash as well (the 'plus' indicated in Table 7). Land was the most frequently used type of bequest in the all time periods studied and at all levels of wealth. But before moving on to discuss the devolution of land to widows, it is helpful first to consider the alternatives.

Dwelling and maintenance arrangements normally allowed generous provision for the widow. However, while arrangments such as these provided more security and relief from responsibility than other types of bequest, they also restricted a widow's freedom and independence, limiting her possible actions. Typical is the arrangement outlined in the will of Robert Bisshop of Marsham in $1556 .{ }^{45} \mathrm{He}$ requested:

that Agnes my wife shall have her dwelling in my place where I dwell for the term of her life and all the utensils in my house to give them where she will. Item I will that she shall have every year 40 shillings and four combs of wheat and two combs of malt and two combs of rye. Item I will that she shall have the occupying of my milk neat and that she shall have twenty ewes and twenty lambs and ten wethers.

Robert's adult son, Edmund, received possession of Robert's houses and land, and was required to fulfil his mother's bequest. The widow could be required to live either with a relative, as was the case in nine of the arrangements here, ${ }^{46}$ or allowed to live alone with her food and other necessities brought to her. Dwelling and maintenance agreements are not found only in wills. They also appear in the court rolls. Land transfers record men, women and couples, presumably all elderly and wishing to retire from active farming, exchanging land in return for dwelling rights and maintenance for the rest of their lives. Twelve such agreements appear in Hevingham's surviving court rolls of 1444-1558; they are spread quite evenly through time, and only five of the agreements found in the court rolls were between relatives. ${ }^{47}$ As bequests in men's wills indicate that widows were more likely to receive land than sons, it may have been just as common for the widow to be head of household, and her unmarried son to receive board and maintenance. Widows with sons were more likely to receive a bequest of land than widows without sons.

Dwelling arrangements were not particularly common in the wills studied here, occurring in 11 per cent of wills that mentioned widows. ${ }^{48} \mathrm{~A}$ similar but slightly higher incidence, of 15 per cent, occurred in the wills of King's Langley, Hertfordshire, between 1523 and 1659, and Kibworth Harcourt, Leicestershire, between c.1550 and c.1750. Erickson found much lower rates, of between 0 and 3 per cent, in wills from Sussex, Lincolnshire and Yorkshire. ${ }^{49}$ In a study of Suffolk wills, Botelho found that while dwelling arrangements occurred frequently in the fifteenth century, appearing in 23 out of 34 wills examined, they were less common in the sixteenth century, and even less so in the seventeenth century. She 
concludes that provision of dwelling and maintenance was a declining practice.$^{50}$ The wills examined here do not support this conclusion: if anything the incidence of dwelling arrangements increased over time. Instead, the most obvious feature of these agreements is their correlation with the will-maker's wealth. One in four 'wealthy' will-makers arranged for his widow's dwelling and maintenance, in comparison to only one in twenty-five 'poor' will-makers.

Bequests of cash and goods, and of goods only, were quite stable in their incidence over time, but again varied considerably according to the will-maker's wealth. This is in part a function of the way in which willmakers' wealth has been measured, in terms of cash bequests. However, we can still infer that a will-maker needed to be of a certain level of wealth to leave a cash bequest, and if he could not afford it, he would leave his widow goods instead. Thus bequests of goods alone were largely the preserve of the poorest will-makers. ${ }^{51}$ Cash and goods were a more mobile form of bequest than land or dwelling arrangements, and were therefore more convenient if the widow wished to move and remarry. By the mid sixteenth century, however, bequests of cash and goods may have lost some of their value relative to land, with the price of land increasing rapidly from 1530 onwards. ${ }^{52}$

Land was the most common type of bequest received by widows, found in 57 per cent of wills that mentioned widows. As some wills did not mention land at all, either because the will-maker was landless or because the land had been disposed of by other means, a second set of figures is provided, showing bequests of land as a proportion of wills mentioning widows and land. They demonstrate a trend not apparent in the raw totals: the proportion of bequests of land to widows in wills mentioning land falls steadily, although not dramatically, between the three time periods, from 80 per cent in the fifteenth century to 64 per cent in the mid sixteenth century. This correlates with an increase over time in the number of bequests of land to sons. ${ }^{53}$ Both trends are associated with a decreased availability of land in the market, and the rapidly increasing price of land. Amussen's study of Cawston, however, shows that 72.5 per cent of married male will-makers with land left land to their widows in the period 1590-1659, suggesting either that the decline was not permanent or that there was considerable variation from parish to parish, even within northeast Norfolk. ${ }^{54}$ Bequests of land are recorded as such in Table 7 simply if the widow was given any amount of land in any form, and this encompasses a variety of practices. Some widows were given land for a term which was for less than their lifetime; other widows received land for their lifetime only, thus precluding rights to bequeath or sell that land. Those widows who were given full rights to land, the right to transfer, 
TABLE 8

The different types of bequests of land to widows in men's wills in six Norfolk parishes, 1440-1579

\begin{tabular}{|c|c|c|c|c|c|c|c|c|c|}
\hline & \multicolumn{2}{|c|}{$\begin{array}{c}\text { Only given } \\
\text { land } \\
\text { temporarily }^{a}\end{array}$} & \multicolumn{2}{|c|}{$\begin{array}{l}\text { Only given } \\
\text { land for } \\
\text { lifetime }\end{array}$} & \multicolumn{2}{|c|}{$\begin{array}{l}\text { Given part of } \\
\text { landholding to } \\
\text { give and sell }\end{array}$} & \multicolumn{2}{|c|}{$\begin{array}{l}\text { Given whole } \\
\text { landholding to } \\
\text { give and sell }\end{array}$} & \multirow{2}{*}{$\begin{array}{c}\text { Total } \\
n\end{array}$} \\
\hline & $n$ & $\%$ & $n$ & $\%$ & $n$ & $\%$ & $n$ & $\%$ & \\
\hline Total & 15 & 19 & 19 & 24 & 15 & 19 & 30 & 38 & 79 \\
\hline 'Poor' & 3 & 6.4 & 10 & 21.3 & 8 & 17.0 & 26 & 55.3 & 47 \\
\hline 'Not poor' ${ }^{\prime b}$ & 12 & 37.5 & 9 & 28.1 & 7 & 21.9 & 4 & 12.5 & 32 \\
\hline With son/s & 13 & 23.2 & 17 & 30.4 & 11 & 19.6 & 15 & 26.8 & 56 \\
\hline Without son & 2 & 8.7 & 2 & 8.7 & 4 & 17.4 & 15 & 65.2 & 23 \\
\hline
\end{tabular}

${ }^{a}$ In six wills land was given until a son was of a certain age, in one until a grandson was of a certain age, in seven for a wife's widowhood only and in one until a son was of a certain age and for widowhood only.

${ }^{b}$ Either 'middling' or 'wealthy'; see Table 6 for definitions.

Source: Wills of probate courts as detailed in note to Table 4.

might receive all, or only a part, of their husband's landholding. Table 8 divides bequests of land into these four categories. ${ }^{55}$

When no will was made, rights of dower allowed a widow one-third of her husband's freehold land for her lifetime only, with the land passing to her eldest son after her death. As we have noted, rights of dower in customary land are not evident in Hevingham Bishops. However, in other parts of England where the custom was in force, rights of dower or freebench in customary land usually approximate a freehold dower, giving the widow all, a half or a third of her husband's land, either for her lifetime or for her widowhood only.$^{56}$ The tenure of copyhold for three lives, common in midland and southern England in the early modern period in which the lives were those of a man, his wife and their son - resulted in the widow having a lifetime interest in all her husband's copyhold land, and thus was equivalent to the most generous form of freebench. In eastern England, however, copyhold of inheritance dominated, and thus when a man died in possession of copyhold land that had not been bequeathed, it devolved according to the custom of the manor.

Of the types of bequests of land shown in Table 8, only bequests to the widow of all her husband's land to hold or transfer exceeded the rights given to a widow by freebench or dower. This was the most frequently used type of bequest but, as we might expect, it was most commonly used by poorer will-makers and by will-makers without sons. Bequests of land 
for a term, and bequests for the widow's lifetime only, approximate customary freebench. They were noticeably more common among willmakers with sons, while bequests for a term were largely the preserve of more wealthy will-makers. We should not forget, however, that a further 33 wills mentioned land but gave none to the widow, so the overall pattern was not one of widows receiving more than was customary elsewhere. As with the landholding arrangements facilitated by a wife's joint tenure, the utilization of individual choice in the devolution of land resulted in some widows getting more and some less than they would have received if customary freebench had applied. In terms of access to land, widows overall appear to have lost out. However, as with daughters' inheritance, widows who did not receive land often received generous cash bequests instead. Todd encountered a similar pattern in seventeenth-century Berkshire when she compared Long Wittenham, a manor with strong rights of freebench, with Sutton Courtney where no rights of dower applied to customary land. ${ }^{57}$

A final aspect of men's provision for widows in wills that deserves consideration is the attachment of conditions to the receipt of particular bequests. Two types of conditions are of particular interest: the stipulation that the widow should give up her rights in the rest of her husband's land and goods, and the stipulation that a bequest was forfeit if the widow remarried. In 16 of the wills there was a condition that the widow had to be up 'rights and interests' to some or all of her husband's property. In 13 cases this condition was attached specifically to land, in 2 cases to land and goods, and in 1 case it was unspecified. If the wife refused to give up her rights, the wills typically stated that all the bequests made to the widow would be void, although some wills were more moderate, with the widow only forfeiting certain bequests. The conditional bequest suggests that the male will-maker accepted that his wife was giving something up by receiving the alternative form of bequest, that the wife did have legally enforceable rights to her husband's land. Most of the wills left these rights unspecified; it was simply 'such right, title or interest as she has or may have'. Six of the wills were more specific. James Bell of Corpusty, yeoman, in 1568 stipulated that his wife Agnes should claim no 'third part' in his lands. Four Scottow men - Robert Larke in 1557, William Hennant and John Moulton in 1559 and Stephen Wymer in 1564 - all specified that their wives should give up their right of dowry or dower, using similar wording in each will. William Allyns of Saxthorpe in 1571 covered all possible scenarios stating that

provided always that if my said wife shall after my departing by any means seek by reason of marriage or otherwise to take any benefit of my houses, lands and tenements by dowry or any other manner of challenge than before excepted or if she shall encumber or any other 
in her name, my executors, contrary to this my will that then I will the said Margery to have no part of those legacies before given to her nor any part or parcel thereof...

Considering the absence of overt evidence of a widow's right to dower in customary land in the court rolls of Hevingham Bishops, how should we interpret these stipulations? They may refer largely to freehold land, which was commonly held even by smaller tenants in this part of Norfolk: although two of the wills specified customary land the others were not specific. It is also possible that rights of dower or freebench existed in the other manors in the parishes from which wills were studied, although no evidence for this has yet been found, or that widows' rights had been dormant and were increasingly being revived in the second half of the sixteenth century, raising anxieties among male will-makers. ${ }^{58}$ Of the 16 wills, 13 date from between 1556 and 1579. There is evidence elsewhere of a growing tension surrounding widows' rights to land in this period. Sreenivasan notes a number of disputes over widow's rights in the court rolls of Earls Colne, Essex, in the second half of the sixteenth century and the subsequent abolition of rights of freebench in 1595, while Todd documents the demotion of freebench in Long Wittenham from a life estate to one of widowhood only, in the 1580s. ${ }^{59}$

Most of the men who asked their widow to give up some rights were relatively wealthy, and left the widow well provided for with cash, goods, livestock, grain and even other pieces of land. For example, Robert Larke of Scottow left his wife Agnes a tenement in Norwich, which had been hers before they married, and another tenement with land in the village of Swanton Abbot for the term of her life, half his 'household stuff', pigs, poultry, two cows, a mare and a foal. At the other extreme, three wills stood out as being miserly in both the extent of the widow's provision and in requiring her to give up rights she could have asserted. Interestingly all these widows can be identified as the will-maker's second or subsequent wife. All three were bequeathed everything they brought into the marriage. It is possible that these are cases where the woman had arranged a settlement to protect her own property before entering marriage, as described by Erickson. ${ }^{60}$

The second type of stipulation, the restriction of a bequest to the wife during her widowhood, was found in only 13 wills, or 9 per cent of wills mentioning widows. This is within the range found by Erickson in her survey of early modern wills, of between 7 and 12 per cent.$^{61}$ Restriction to widowhood meant that if the wife remarried she lost her right to that bequest. It was most commonly found in wills of men of middling wealth, and was spread evenly over time.$^{62}$ Unlike the requests for widows to give up rights, restrictions to widowhood were always applied specifically to prescribed gifts of land, dwelling or grain for maintenance, and did not 
carry wider penalties. Six of the wills offered the widow land if she remained single and cash if she did not. Four wills provided the widow with dwelling and/or grain as long as she was unmarried. Three wills gave the widow land if she remained unmarried and offered no compensation to her if she did not.

The restriction of certain bequests to a woman's widowhood has been interpreted as an expression of a man's jealousy over his wife's person after his death: the removal of the legacy on the wife's remarriage serving to punish and discourage her from taking such action. ${ }^{63}$ It has also been suggested that it was a necessary measure to avoid property being alienated from the first husband's offspring by a second husband ${ }^{64}$ While some historians have argued against this viewpoint, they have done so on the basis of the low incidence of restrictions to widowhood in their particular collections of wills. ${ }^{65}$ In the case of the wills studied here, the argument that the restriction manifests male jealousy and concern for children's inheritance cannot be upheld. With regard to the bequests of dwelling or maintenance, the more obvious conclusion is that these bequests were designed to support the widow while she was single, and because she was single. If she remarried the will-maker assumed that her new husband would support her, a fairly straightforward assumption in this period. The studies of Spufford, Erickson and Botelho have noted that it was dwelling and maintenance arrangements that were most commonly conditional on the widow remaining unmarried. ${ }^{66}$ In the case of the bequests of land being swapped for bequests of cash, the jealousy seems to relate to land and not to the woman. If the remarriage of the woman was the issue, why offer her cash on the occasion of her remarriage? Nor can we conclude that husbands applied such restrictions to ensure that the property passed to their children. In all six cases the land was to be sold to provide the woman with a cash alternative, and in only one case was it stipulated that the land should be sold to one of the couple's children. Instead, it seems that what we are observing here is a reluctance to let another man obtain the land 'for free', simply by marrying the widow.

The three wills in which the woman was given land for her widowhood only and was offered no compensation are of particular interest because they fit the stereotype more closely. In 1460 William Stubbe of Scottow left his land to his wife Margaret for her lifetime if she remained unmarried. However Margaret was also given a very large cash bequest of $£ 6613 \mathrm{~s} 4 \mathrm{~d}$, all the household goods and a supply of grain, none of which were conditional on her remaining single. She clearly did not need the land in order to survive. The land was to go to their son John after her death or at her remarriage, but he was required to pay for it at a price of $13 \mathrm{~s} 4 \mathrm{~d}$ 
per acre of arable land ${ }^{67}$ Here the husband's concern seems to be that the land be passed to the heir and be paid for, rather than a specific concern about Margaret's remarriage. In his will of 1524 John Page of Saxthorpe gave his land to his wife until their son reached the age of 22; if she remarried then his executors were to manage the land until then. Either way, the bequest of land to his wife was only temporary: John Page's concern seems to have been the management of the land, not his wife's welfare or behaviour. The 1556 will of James Shakell, also of Saxthorpe, is rather different. He left his wife almost all his houses and land for her lifetime. In his words this was 'so that she keep herself a widow'. He did not mention remarriage, or what should happen if his wife took that course, but he did make her joint executor with their son, suggesting a degree of trust and agreement. Rather than seeing the provision as one in which a husband discourages his wife's remarriage, perhaps this will should be interpreted as a wife ensuring that her husband gave her the option of remaining single, the option she preferred.

The wills of wealthier men included arrangements, such as splitting land between wife and son or giving the wife dwelling or temporary rights only, which ensured that the wife's remarriage would not completely disinherit one or more sons. While there is little evidence of hostility to remarriage in the period studied here, Todd suggests that attitudes began to change in around 1570, with an increasing hostility among wealthy will-makers, marked by an increased incidence of restrictive clauses. ${ }^{68}$ In this study it was poorer men, however, who were the most likely to give all their land, with full rights, to their wife. Within this section of the community, we can speculate that a widow's remarriage was seen in a rather different light, that of economic necessity. If the couple's children were young, it is likely that their mother's remarriage would be beneficial for them. The economic position of a widow who had received little wealth from her husband, especially if she had young children, was extremely precarious. If she had land it was easier to find a new husband to help provide not only for herself but for the children of her first marriage. It can be argued that in making their wills some dying men were aiming to aid, not hinder, their wife's remarriage. Even in the later period, Todd found that widows with minor children were more likely to remarry than widows with no children. ${ }^{69}$

The provisions for widows in men's wills suggest that men did consider women capable of managing land and financial matters. Men frequently appointed their wives as executrices and left them bequests of land. In the absence of customary rights of dower there was more flexibility in the provision for widows in north-east Norfolk than is found in manors where strong rights of freebench held force; some widows received more and 
some less. Overall it is likely that widows in north-east Norfolk received less land, but this was compensated for to a certain extent by other types of bequests. Almost all male will-makers showed concern for their wife's welfare during her widowhood, and did not discourage possible remarriage. However, wealthier will-makers seem to have balanced concern with stronger anxiety regarding the fate of their landed property, in particular a concern that it should be paid for before it passed into the hands of another man. While wealthier will-makers gave their widows a smaller proportion of their wealth than did poorer will-makers, the widows of wealthy men received more in absolute terms.

\section{WHAT WIDOWS ACTUALLY DID}

Wills provide copious amounts of information about the provision a husband made for his wife's widowhood. Information about what a widow actually did after the death of her husband is less easy to come by, and we rely here on detailed study of Hevingham's court rolls, combined with information from Marsham's parish registers. ${ }^{70}$ Evidence from elsewhere demonstrates that some widows maintained themselves as independent farmers, and were often capable managers of landholdings. ${ }^{71}$ While it is unlikely that, on average, a widow could maintain a household at the same economic level is a married couple, some women clearly preferred to remain single. As well as farming actively, landholding widows had the option of subletting their land. Unfortunately, while we can infer that some non-resident tenants in Hevingham Bishops may have sublet their land, subletting is not recorded in the court rolls and so we have little concrete evidence. In Long Wittenham, Berkshire, in the seventeenth century, Todd found that while male tenants were regularly recorded subletting land in the court books of $1550-$ c. 1700 , 'on only one occasion in this period did a widow receive permission to do so'. ${ }^{72}$

It is not difficult to find examples of long-term landholding widows in Hevingham's court rolls. For instance, Isabel Hawe was widowed in 1508 and continued to hold her four-acre holding until 1529, when she sold it, apparently to a non-relative, in return for an unspecified payment. Her only known relative was a 14-year-old son mentioned in the court roll of 1509, but who does not appear again. Joan Elwyn was widowed in 1522. She was probably elderly in 1536, when she surrendered a two-acre holding to her daughter and son-in-law in return for a lifelong maintenance agreement. But it was not until 1542, perhaps on her deathbed, that she surrendered her main five-acre holding. Of a rather different social class was Margaret Bisshop of Marsham, a minor gentlewoman whose husband William held a small manor in Crosthwaite 
and land in nine other north-east Norfolk villages as well as Marsham. They were childless and Margaret received all his landed property when he died in 1546. She did not remarry, and in her will of 1565 she left bequests to a male and female servant and to a number of Marsham women of more humble status, suggesting that she had been resident and active in the community in the years since her husband's death.

However, such women stand out precisely because they were unusual. Most widows did not maintain sole possession of land for long. Using the court rolls, wills and the parish register, detailed landholding histories of 50 male tenants of Hevingham manor who died between 1473 and 1562 were reconstructed, demonstrating how their property was divided between their widow and children, and what happened in the years after their death. Of these tenants 42 left widows, of whom 31 received land. Thus 74 per cent of these widows received land, a slightly higher proportion than the 71 per cent found in wills that mention land.$^{73}$ Yet, in the first half of the sixteenth century, the proportion of female tenants on this manor was not more than 13 per cent, according to the survey data discussed in Section I, above. This disparity can be explained by comparing the landholding histories of men with that of their widows. While men held land in the manor for an average of 24.5 years, the widows who received land held it for an average of only 5.9 years. Only 10 per cent of widows held land for 20 years or more, in comparison to at least 56 per cent of the men. ${ }^{74}$ However, some men did not leave widows and some widows did not receive land. Looking at the 43 couples for whom a landholding history of both the man and his wife, if he had one, could be reconstructed in full, the number of 'landholding years' experienced by men and widows was compared. Men accounted for 1,065 landholding years and widows for 161 , or 13 per cent of the total, a figure that compares well with the 10-13 per cent female landholders recorded in manorial surveys.

Why did widows hold their land for such a comparatively short time? The actions of the 28 landed widows who could be traced fell into three groups. Twelve widows held their land until death, existing as independent landholders for an average of nine years. More commonly, however, widows either granted their land to a new husband, or sold it. The nine widows who regranted land to a husband held land on their own for an average of only four and a half years, while those who sold their land on average held it for only two years. This makes an interesting comparison with Todd's study of late-sixteenth- and seventeenth-century Long Wittenham, where widows had right of freebench in the whole of their husband's holding as long as they remained unmarried. Of the 48 freebench-holding widows for which Todd could provide a full history, 34 
TABLE 9

The remarriage of tenants' widows in Hevingham Bishops, 1509-1546

\begin{tabular}{lrr}
\hline \hline & $n$ & $\%$ \\
\hline & & \\
(a) & 102 & \\
Number of marriages & 27 & 26 \\
Husband's death could not be traced & 28 & 27 \\
Woman died while married & 47 & 46 \\
Woman widowed & & \\
(b) & 47 & \\
Number of times women were widowed & 16 & 34 \\
Woman died while widowed & 16 & 34 \\
Definitely remarried & 15 & 32 \\
Sold land and disappeared from record while widowed & & \\
\hline \hline
\end{tabular}

Source: Hevingham Court Rolls, Norfolk and Norwich Record Office, Norwich (see note 7).

held land until they died, on average for nearly twelve years. The other 14 widows held land for an average of nearly seven years, 5 giving up their land at remarriage and 9 surrendering their land for other reasons: Todd suggests retirement. Reconstructing the history of landholdings, Todd calculates that widows held land for 20 per cent of the time, while a court book of 1659 shows that 20 per cent of tenants were widows. ${ }^{75}$ The different patterns in Long Wittenham and Hevingham were the result not only of the differing rights widows had to their husband's land but also of the more active land market in Hevingham and higher rates of remarriage among landholding widows. For Hevingham, 12 of the widows traced in the detailed landholding histories remarried at least once, or 28 per cent of the 43 widows. All of these widows had received land from their first husband, so the rate of remarriage for widows with land was higher, at 39 per cent. ${ }^{76}$ In Long Wittenham, only 5 out of 48 landholding widows remarried, or 10 per cent.

To assess the rates of remarriage for women more generally, but in less detail, the actions of all those women who held land in the manor of Hevingham, with or after their husbands, during the period 1509-1546 are shown in Table 9. There were 102 marriages, or married names of women. because some women married more than once, these names belonged to only 86 different individuals. Tracing tenants, men and women, is complicated by the active land market and high turnover of tenants characteristic in this manor and, more frustratingly, by a number of gaps in the court records scattered throughout the period. As a result, 26 per 
cent of marriages could not be traced to their conclusion. As would be expected, a number of women died while married, but a higher proportion, 46 per cent, are known to have been widowed. Observing the actions of these widows, equal numbers can be shown to have remarried and died without remarrying. A further category, roughly one-third, consists of widows who surrendered their land and disappeared from the record. We can speculate that this last group of widows did leave the manor, and are more likely to have remarried than not, as this may have been their reason for leaving, but there is no solid evidence for this. If we look at just those widows for whom we have a certain history, half remarried. Todd, in her study of remarriage in Abingdon, Oxfordshire, disregarded all the 'don't knows' from her statistics, and found exactly the same rate of remarriage, 50 per cent, among widows in the period 1540-1599. The rate of remarriage in Abingdon declined markedly over the next century, to 37.5 per cent in 1600-1659 and 23.5 per cent in 1660-1720. ${ }^{77}$

While there is a growing literature on widows' remarriage, evidence is still fragmentary. On the basis of existing work, two areas of consensus are emerging. First, the proportion of widows remarrying declined during the early modern period. The high level of widow remarriage in the sixteenth century was replaced by lower levels in seventeenth century. ${ }^{78}$ The trend between the medieval period and the sixteenth century is less clear. While the proportion of widows remarrying during the pre-Black Death period may have been as high, if not higher, than in the sixteenth century, it seems likely there was some decline during the late fourteenth and fifteenth centuries. ${ }^{79}$ Using probate registers from the city of York, Goldberg found that the proportion of widows who remarried was between 6 per cent and 17 per cent during the period $1389-1520 .{ }^{80}$ However, the factors affecting remarriage in urban York are likely to have been rather different from those affecting rural, landholding widows. The second area of agreement is that rates of remarriage in rural England were connected to patterns of landholding, in particular whether the widow was given land or not, and to the overall demand for land. ${ }^{81}$ Assuming that throughout the period from the thireenth to the early eighteenth century, marriage was viewed in economic terms as well as, or instead of, romantic ones, and that widows were likely to remarry if it was economically advantageous for them to do so, the possession of land by widows can be seen to have encouraged remarriage in two ways. In the first place, it was easier to work land with the help of a husband. Without a husband certain tasks, such as ploughing, required hired labour, and clearly two people could manage more work than one. ${ }^{82}$ Secondly, land was a form of wealth, and possession of wealth enabled widows to make a better match, marry a wealthier or more able man, and thus establish a more secure marital 
household. Therefore it could be argued that the trend towards widows remarrying less frequently was the result of widows' declining access to land. However, there are complications with this argument. As in Long Wittenham, some forms of tenure discouraged widows from remarrying by giving them rights to their former husband's land only if they remained single: in such circumstances many women preferred to retain their land rather than remarry. ${ }^{83}$ Additionally, it is unclear why the replacement of land with cash bequests of a similar value should have decreased the propensity of widows to remarry: it might have made remarriage easier, by allowing widows greater geographical mobility without loss of wealth.

Any explanation of changing trends in remarriage must take into account not only widows' access to land but more general changes in the social distribution of wealth. Widows of a middling level of wealth were the most likely to remarry in the early modern period. ${ }^{84}$ Wealthy widows remarried less because they could live comfortably without remarrying, and may have been more concerned about retaining personal control of their property rather than submitting to coverture. Poor widows remarried less because they simply did not make attractive marriage partners in economic terms; they had nothing to offer but their labour, and if they were elderly, even their labour potential was limited. It is also possible that the increasingly systematic provision of poor relief from the late sixteenth century onwards had a negative impact on the proportion of widows remarrying. For instance, Wales cites cases of widows receiving poor relief for long periods of time, in some cases for over 30 years, in seventeenthcentury Norfolk. Were these widows unable to remarry, or did the provision of poor relief allow them to make the choice to remain single ? ${ }^{85}$

\section{CONCLUSION}

Rights to land, and patterns of landholding and inheritance, were complex and varied in medieval and early modern England. In examining women's access to land we add another layer of complexity. Women's legal rights, their economic position and cultural attitudes to women, are hard to summarize beyond their most basic aspects. It is therefore difficult to generalize about the extent of landholding by women, and attitudes to women holding land. However, the contrasts explored in this article between men and women, daughters and widows and the landholding patterns in different manors - allow us to suggest four important factors that influenced the extent to which land was given to different types of women, at different times and places.

Two of these factors inhibited women from becoming landholders. First, men had stronger and more effective legal rights to property than 
women. They were stronger because women's rights were eclipsed during marriage, and more effective because the legal system that upheld property rights, the manorial and other courts, was controlled by men. Male control over property and the enforcement of rights in property were connected with the second factor: a strong cultural norm that men were more suitable household heads and property-holders than women. While this point has not been discussed in any detail in this article, it is inherent in the data presented. ${ }^{86}$ Women made up a minority of landholders, married women were not named as tenants, sons were preferred to daughters as the inheritors of land. These factors interacted: women were considered less suitable recipients of land because their legal rights were weaker than men's; the fact that women were less likely to hold land or be heads of household than men explains, in part, their lesser involvement in the legal system. It can also be argued that these two factors have a common root: the misogynist nature of cultural values in medieval and early modern England. While the holding of land by women independently was discouraged, there was no cultural or legal bar to them doing so outside marriage, and the frequency with which widows received land, and held land as sole landholders, demonstrates that women were known to be capable landholders. This allowed room for variations in attitudes. For instance widows seem to have been more acceptable landholders than young never-married women. Daughters were apparently considered more acceptable recipients of land in Yorkshire than they were in Norfolk. Before we ascribe all variations to differences in cultural attitudes, we need to consider more concrete variations in circumstances.

In explaining the fact that some women did receive land, previous studies have tended to stress family inheritance strategies. The function of widows as landholders was to act as a 'bridge', ensuring that land passed from father to son, even if the son was not old enough to manage a landholding competently at the time of his father's death. ${ }^{87}$ Daughters received land because some families had no sons. Evidence from northeast Norfolk, where dynastic attitudes to landholding were not predominant among ordinary tenants and where land was frequently not kept within the same family from generation to generation, suggests that these explanations are inadequate. They pay little attention to widows' or daughters' actual needs or the variations in land tenure that determined the choices available to tenants. For this, two additional factors need to be brought into play. The third factor is the economic position of women. Women's ability to generate income was limited. Women were only considered capable of carrying out certain types of work, and their pay was lower, on average, than that of men. There is good evidence that young, unmarried women could support themselves independently, by 
working as servants, even if their ability to accumulate wealth was less than that of young, unmarried men. ${ }^{88}$ It was elderly widows and widows with young children who were in the worst economic position. Such women had extreme difficulties supporting themselves independently unless they had land or were provided with dwelling and maintenance. Here we have an explanation for the contrasting treatment of daughters and widows, and of widows and sons.

Daughters were residual recipients of land. They were considered less suitable landholders than sons, and less needful than widows. In northeast Norfolk daughters' need to receive land seems to have been considered negligible or even negative. Daughters needed wealth to make a good marriage match. But in providing this inheritance parents seem to have regarded cash and goods as more suitable and convenient than land. Parents sold their land rather than giving it to daughters. We cannot agree with Erickson's conclusion that in comparison to gifts of cash the value of land was mainly symbolic. ${ }^{89}$ Gifts of land from parent to child were typically considerably more valuable than were gifts of cash. Daughters and sons who received cash rather than land lost out. Although not all sons received land, they remained much more likely to receive it than daughters. When it comes to comparing the treatment of sons and widows, however, there was a great deal of variation in who took priority. The situation varied according to the age of the two parties, the family's level of wealth and the availability of land. In practical terms, if the son was very young the widow was the more suitable recipient of land, whereas if the widow was elderly the opposite was true. In each case the stronger was usually expected to support the more vulnerable. Wealthy men could split landholdings or provide widows adequately with non-land property and thus diffuse the competition between widow and son. Poorer men normally favoured their wife over their sons. The availability of land also affected the choices made. In the fifteenth century when land was relatively easy to acquire, widows took priority, largely because sons found it easy to obtain land from outside the family. In the sixteenth century, as the price of land rose, sons were increasingly favoured over widows, especially by wealthier landholders. Sons, however, were increasingly required to pay for their inheritance of land, part of the payment being to the widow. This arrangement was perhaps more effective than the reverse, with a married son being able to generate more income from the landholding than a widow could have on her own. Thus a landholding son paying his mother's dower could generate more income for the family as a whole than a landholding widow paying her son's inheritance.

The final factor we have to consider is the pattern of landholding and 
terms of tenure - the way in which land was held. This encompasses the demand for land, manorial customs and the ability to buy and sell land. We have just seen how demand for land could effect the balance of landholding between widow and son. Terms of tenure largely explain the differences between the number of widows holding land and remarrying in sixteenth- and seventeenth-century Long Wittenham and in sixteenthcentury Hevingham. In Hevingham land tenure gave widows no rights to their husband's land, but left tenants free to design their own arrangements. The presence or absence of a land market was also important. On many manors in southern and midland England it was difficult for tenants to buy and sell customary land, because of restrictive forms of land tenure. The active land market we encounter in Norfolk was absent. Its absence narrowed the types of provision that could be made for widows and the types of inheritance that could be given to sons and daughters: it was less easy to generate cash by selling land, and less easy to purchase land with that cash. The frequent use of cash to provide for widows' dowry, but especially to provide for daughters' inheritance, was in part a function of the land market. The fact that daughters with no brothers frequently received land in other parts of the country may be the result of the absence of a Norfolk-type land market: it was less easy to convert land into cash.

In summary, women's inferior legal rights and a cultural hostility to female landholders provide an explanation for the generally low numbers of women holding land. The precarious economic position of women and their resulting needs explain why many women did receive land, while the differing needs and circumstances of particular women explain why families in the same manor might follow quite different strategies in the devolution of land. Variations in demand for land and terms of tenure explain many of the differences between manors. Combined, demand for land, terms of tenure and cultural attitudes go a long way to explaining both regional differences and changes over time. Viewing the extent of women's access to land over the whole of England and across the long sweep of time from c. 1250 to c. 1750 , the degree of continuity is more striking than the extent of change, with women rarely making up more than 20 per cent of landholders..$^{90}$ That the situation remained stable, despite momentous social economic changes such as the end of serfdom, increased landlessness and the commercialization of the rural economy, suggests that cultural attitudes were indeed important in determining women's access to land, and that these attitudes were extremely pervasive over time. However, it is only by examining the minutiae of women's social and economic position, both geographically and over time, that we can come close to understanding how women's subordination was upheld 
and re-formed in a constantly shifting situation to maintain this pattern of continuity.

\section{ACKNOWLEDGEMENTS}

Most of the data presented here was collected during the research for my D.Phil. thesis, 'The development of agrarian capitalism in England from c.1450-c.1580', under the supervision of Richard M. Smith, to whom I owe many thanks. The production of this article was spurred on by a conference on 'Widowhood: constructions and conditions' at Exeter University in May 1996, and I would like to thank Lynn Botelho for providing me with a copy of the paper she presented there.

\section{ENDNOTES}

1 Amy Louise Erickson, Women and property in early modern England (London, 1993), 223.

2 See Nesta Evans, 'Inheritance, women, religion and education in early modern society as revealed by wills', in P. Riden ed., Probate records and the local community (Gloucester, 1985); Susan Dwyer Amussen, An ordered society: gender and class in early modern England (New York, 1988); Tim Wales, 'Poverty, poor relief and the life-cycle: some evidence from seventeenth-century Norfolk', in Richard M. Smith ed., Land, kinship and life-cycle (Cambridge, 1984); and Lynn Botelho, " "The old woman's wish": widows by the family fire? Widows' old age provisions in rural England, 1500-1700', unpublished paper; see also Lynn Botelho, 'Provisions for the elderly in two early modern Suffolk communities' (unpublished Ph.D. thesis, University of Cambridge, 1996).

3 Barbara Todd, 'Freebench and free enterprise: widows and their property in two Berkshire villages', in John Chartres and David Hey eds., English rural society, 1500-1800: essays in honour of Joan Thirsk (Cambridge, 1990); Sylvia Seeliger, 'Hampshire women as landholders: common law mediated by manorial custom', Rural History 7 (1996), 1-14. Margaret Spufford, in Contrasting communities: English villagers in the sixteenth and seventeenth centuries (Cambridge, 1974), uses both manorial documents and wills, but does she not examine women's role as landholders in any great detail.

4 Evans's 'Inheritance, women, religion and education' is a notable exception.

5 Brigstock is studied by Judith M. Bennett in Women in the medieval English countryside: gender and household in Brigstock before the plague (Oxford, 1987); Long Wittenham is studied by Barbara Todd in 'Freebench and free enterprise'; for Hevingham, see below.

6 See Jane Whittle, 'The development of agrarian capitalism in England from c.1450-c.1580' (unpublished D.Phil. thesis, University of Oxford, 1995), especially chapter 3. See also my 'Individualism and the family-land bond: a reassessment of land transfer patterns among the English peasantry c.1270-1580', Past and Present (forthcoming), in which the complexity of inheritance patterns and the significance of regional difference are discussed in more detail.

7 Norfolk and Norwich Record Office, Norwich (hereafter NRO), Hevingham Court Rolls, NRS 19559 42D2, NRS 14763 29D4, NRS 19560 42D2, NRS 13685 28D3, NRS $1447729 \mathrm{C} 1$, NRS 14487 29C1. Historically this manor is simply called 'Hevingham'. It belonged to the Bishop of Norwich until 1536 and I refer to it here as Hevingham Bishops to distinguish it from Hevingham Cattes, another manor in the same parish. When I refer to 'Hevingham', I mean either Hevingham Bishops manor or the parish of Hevingham, but never Hevingham Cattes manor. 
8 Whittle, 'The development of agrarian capitalism', 224-8. Marsham's parish register survives for the period $1538-1556$.

9 Ibid., 196-224. The estimates are calculated from the Muster returns of 1522, using a multiplier of 3.238 for every man assessed.

10 The probate courts are the Norwich Consistory Court, Norwich Archdeaconry Court and the Norfolk Archdeaconry Court. The wills are located at the NRO.

11 NRO, Hevingham rental 1509, NRS 14759 29D4; NRO, Hevingham court roll 1509-1547, NRS 13685 28D3, first court of James Boleyn, 31 Henry VIII, Thursday after Easter, attornment of tenants.

12 Bruce M. S. Campbell, 'Population pressure, inheritance and the land market in a fourteenth-century peasant community', in Smith ed., Land, kinship and life-cycle. Percentages calculated from figures in Campbell's Table 2.1, on p. 96; Bennett, Women in the medieval English countryside, 33; Peter Franklin, 'Peasant widows' "liberation" and remarriage before the Black Death', Economic History Review 2nd ser. 39 (1986), 188; Josiah Cox Russell, British medieval population (Albuquerque, New Mexico, 1948), 62-4; J. Z. Titow, English rural society 1200-1350 (London, 1969), 87. A higher proportion of women tenants, 23.1 per cent, is noted in the manors of Waltham and Easter, Essex, in 1328; see L. R. Poos and R. M. Smith, "'Shades still on the window": a riposte', in Zvi Razi and Richard Smith eds., Medieval society and the manor court (Oxford, 1996), 336.

13 Frances Gardiner Davenport, The economic development of a Norfolk manor 1086-1565 (Cambridge, 1906), xvi-xviii; Cord Oestmann, Lordship and community: the Lestrange family and the village of Hunstanton, Norfolk, in the first half of the sixteenth century (Woodbridge, Suffolk, 1994), 46-7; Spufford, Contrasting communities, 68, 71, 135-6, 138-9, 145-7; Todd, 'Freebench and free enterprise', 181; Seeliger, 'Hampshire women as landholders', 12.

14 For example, E. P. Thompson, 'The grid of inheritance: a comment', in Jack Goody, Joan Thirsk and E. P. Thompson eds., Family and inheritance: rural society in western Europe, 1200-1800 (Cambridge, 1976), 328-60; and B. A. Holderness, 'Widows in preindustrial society: an essay upon their economic functions', in Smith ed., Land, kinship and life-cycle, 433.

15 Out of a total of 824 land transfers recorded in the surviving court rolls.

16 Bennett, Women in the medieval English countryside, 33-5, 78-82. Similar proportions of women taking part in the land market as vendors or purchasers, varying between 15 per cent and 28 per cent over five-year periods, are found in Redgrave, Suffolk, between 1270 and 1315, calculated from Table 9.2 in L. R. Poos and Richard M. Smith, " "Legal windows into historical populations"? Recent research on demography and the manor court in medieval England', in Razi and Smith eds., Medieval society and the manor court, 304.

17 Seeliger, 'Hampshire women as landholders', 6-7. Seeliger's figures also refer to surrenders and admissions, and thus are not directly comparable on those grounds. The nature of joint tenure in Hevingham is discussed below in Section III.

18 Todd, 'Freebench and free enterprise', 194-7.

$19 \mathrm{It}$ is not clear if this is the eldest or youngest son.

20 With regard to sons, 24 transfers were deathbed transfers or via executors, 2 were as a result of joint tenure and 5 were inter-vivos land transfers. With regard to daughters, 3 were deathbed transfers or via executors and 1 was as a result of joint tenure.

21 Evans, 'Inheritance, women, religion and education', 62 (percentages are of men's wills in which land or houses were bequeathed); Erickson, Women and property, 61 . 22 Spufford, Contrasting communities, 111. 
23 Erickson, Women and property, 63.

24 Amussen, An ordered society, 91-2.

25 Macfarlane states with regard to daughters' inheritance or marriage portions that 'There was a mixture of constituents in English portions, with an emphasis on movable wealth: the two major items brought by girls as their portions were household furniture and ready cash' (in Alan Macfarlane, Marriage and love in England: modes of reproduction 1300-1840 (Oxford, 1986), 265).

26 Richard M. Smith, 'Coping with uncertainty: women's tenure of customary land in England c.1370-1430', in Jennifer Kermode ed., Enterprise and individuals in fifteenth century England (Stroud, 1991), 48 and 62.

27 Erickson, Women and property, 64; Evans, 'Inheritance, women, religion and education', 64-5; Macfarlane, Marriage and love in England, 266. The term 'goods' and 'moveables' is used here and in following sections to mean moveable possessions, including livestock and grain as well as furniture, kitchenware and so on.

28 Erickson, Women and property, 66.

29 There are three possibilities: more people could afford smallholdings and thus the demand was higher; possession of a smallholding gave access to the manor's extensive common land and thus was disproportionately valuable; and some of the payments may have been due for extra land which is not recorded in the court roll agreement, such as free land or land in another manor.

30 The practice of requiring sons to pay for the land they were bequeathed has been noted widely in early modern wills; see for instance Spufford, Contrasting communities, 106-7; R. W. Hoyle, 'The land-family bond in England', Past and Present 146 (1995), 169; and Erickson, Women and property, 69-70.

31 Marriage was stated in 8 out of 32 cases when an occasion was specified for daughters; in the other cases age was specified.

32 Macfarlane states that daughters occasionally received marriage portions of house and land in Earls Colne, Essex, 'if there were no sons and their parents were dead' (Marriage and love, 266).

33 For instance see Erickson, Women and property, especially page 24.

34 In Hevingham this procedure was only followed in cases where husband and wife were recorded as joint tenants. In other manors the procedure was followed with regard to all land surrenders by married men because of the widow's rights to dower or freebench. See Seeliger, 'Hampshire women as landholders', 5; R. M. Smith, 'Women's property rights under customary law: some developments in the thirteenth and fourteenth centuries', Transactions of the Royal Historical Society 5th series 36 (1986); and Smith, 'Coping with uncertainty'.

35 In particular see Smith, 'Women's property rights', 180-5, and 'Coping with uncertainty', 43-4.

36 Smith, 'Women's property rights', 184-5.

37 Alternatively it might indicate that husband and wife only came to court to surrender the land if they had already agreed. Smith does cite a late-thirteenth-century case where a land transfer was challenged because the jury claimed the wife had not given her consent freely ('Women's property rights', 183-4).

38 Erickson, Women and property, 172.

39 Ibid., 156-61.

40 Ibid., 174 and 186.

41 Ibid., Table 9.1, page 158. An unusually low rate of 46 per cent was found by Evans in Fressingfield and Laxfield, Suffolk, 1372-1540. The highest rates, 89 and 96 per cent, were found in Yorkshire. 
42 Amussen, An ordered society, 82. The widow was appointed sole executrix in 63 per cent of cases; it is not specified whether they had supervisors. Similar rates are also observed by McIntosh in Havering, Essex, 1565-1590: 66 per cent of widows were made sole executrix, and 6 per cent co-executors, while 27 per cent of executors were not the widow; see Marjorie Keniston McIntosh, A community transformed: the manor and Liberty of Havering, 1500-1620 (Cambridge, 1991), 90.

43 Erickson, Women and property, 157.

44 By 'dwelling' is meant the right to live in a room or house, of which the widow was not the owner or formal tenant, while 'maintenance' is taken broadly to mean payments in cash or kind on an annual or more regular basis, for the widow's subsistence. This type of agreement is also known as 'house room'.

45 This is the same Robert Bisshop who had received land from his aunt Alice in 1500.

46 In six cases this meant with a son, in two with a son-in-law (and presumably a daughter as well) and in one case with a nephew.

47 The nature and incidence of such maintenance or 'retirement' agreements in the medieval period is discussed by Smith: he notes that while 64 per cent of agreements observed in the pre-1348 period were between relatives, this was true of only 30 per cent in the period after 1350; see Richard M. Smith, 'The manorial court and the elderly tenant in late medieval England', in Margaret Pelling and Richard M. Smith eds., Life, death and the elderly: historical perspectives (London, 1991), 52.

48 The actual incidence is slightly higher than 11 per cent, as dwelling arrangements where the widow was also given land have not been included in the total.

49 These figures are collated by Erickson in Women and property, 164-5. It is likely that some differences result from the ways historians have defined such agreements.

50 Botelho, 'The old woman's wish', 11-12. The fifteenth-centrury wills come from throughout Suffolk while the sixteenth- and seventeenth-century wills come exclusively from the parishes of Cratfield and Poslingford.

51 It is possible that some of these widows received land as well, as a result of joint tenure.

52 See Table 5, above, for the price of land.

53 Whittle, 'Individualism and the family-land bond'.

54 Amussen, An ordered society, 83.

55 If the duration of the bequest was not stated, it was assumed that the widow received full rights to give and sell.

56 Smith gives examples of the different possible durations of freebench in 'Women's property rights', 169, and examples of freebench at one-third, one-half and all of a holding in 'Coping with uncertainty', 54. See also Barbara Harvey, Westminster Abbey and its estates in the Middle Ages (Oxford, 1977), 297, and Bennett, Women in the medieval English countryside, 164. For seventeenth- and eighteenth-century freebench see Thompson, 'The grid of inheritance', 349-55; H. F. C. Lansberry, 'Free bench seesaw: Sevenoaks' widows in the late seventeenth century', Archaeologia Cantiana 100 (1982), 282; Holderness, 'Widows in pre-industrial society', 432; Todd, 'Freebench and free enterprise', 178-9; and Seeliger, 'Hampshire women and landholders', 3.

57 Todd, 'Freebench and free enterprise', especially 190-1.

58 Of the wills that requested the widow to give up rights, one was from Hevingham and three from Marsham, parts of which lie within Hevingham Bishops; two were from Corpusty, four from Saxthorpe and six from Scottow. Two of the wills, one from Hevingham and one from Saxthorpe, specified that the condition applied to 'bond' or customary land, not freehold.

59 Govind Sreenivasan, 'The land-family bond at Earls Colne (Essex) 1550-1650' Past and Present 131 (1991), 28-31; Todd, 'Freebench and free enterprise', 178-9. 
60 The wills of Alan Mors of Marsham, worsted weaver, 1559; Henry Marsham of Marsham, 1562; and William Allyns of Saxthorpe, 1571. See Erickson, Women and property, 129-51, especially page 137 , for her discussion of ordinary women's marriage settlements.

61 Ibid., 167.

62 The restriction was found in three wills dating from 1440-1499, six from 1500-1539, and four from 1540-1579.

63 For example, Spufford, Contrasting communities, 113, and Erickson, Women and property, 166.

64 See Barbara Todd, 'The remarrying widow: a stereotype reconsidered', in Mary Prior ed., Women in English society 1500-1800 (London, 1985), 74, and Botelho, 'The old woman's wish', 13-14.

65 See Keith Wrightson and David Levine, Poverty and piety in an English village: Terling, 1525-1700 (Oxford, 1995), 97, and Vivien Brodsky, 'Widows in late Elizabethan London: remarriage, economic opportunity and family orientations', in Lloyd Bonfield, Richard M. Smith and Keith Wrightson eds., The world we have gained: histories of population and social structure (Oxford, 1986), 145-6.

66 Spufford, Contrasting communities, 113; Erickson, Women and property, 166; and Botelho, 'The old woman's wish', 8-14.

67 The total acreage is not specified, but he was expected to pay $£ 10$ a year.

68 Todd, 'The remarrying widow', 73.

69 Ibid., 66-8.

70 The registers survive for the period 1538-1556, but are incomplete in places.

71 See Todd, 'Freebench and free enterprise', 187-94; Franklin, 'Peasant widows' "liberation", 197; Lansberry, 'Free bench see-saw', 285; and Erickson, Women and property, 187.

72 Todd, 'Freebench and free enterprise', 192.

73 See Table 7, above.

74 The 46 men whose histories could be reconstructed in full held for 1,128 years altogether, and 28 widows held for 165 years only. Only 3 widows out of 31 held land for 20 years or more, while at least 28 men out of 50 did so.

75 Todd, 'Freebench and free enterprise' 181 and 191-2.

76 Out of 31 landholding widows 12 remarried. Of these 9 granted their land to the new husband while 3 did not. All figures for remarriage are minimums, as the history of some widows could not be traced in full.

77 Todd, 'The remarrying widow', 60-5.

78 Ibid., 60-5; Erickson, Women and property, 196; E. A. Wrigley and R. S. Schofield, The population history of England, 1541-1871: a reconstruction (London, 1981), 351-376.

79 See for example, Jack Ravensdale, 'Population changes and the transfer of customary land on a Cambridgeshire manor in the fourteenth century', in Smith ed., Land, kinship and life-cycle, 197-225, especially pages 206 and 213-23.

80 P. J. P. Goldberg, Women, work and life cycle in a medieval economy: women in York and Yorkshire c.1300-1520 (Oxford, 1992), 267-73.

$81 \mathrm{~J}$. Z. Titow, 'Some differences between manors and their effects on the conditions of the peasantry in the thirteenth century', Agricultural History Review 10 (1962), 1-13, especially pages 7-13; Ravensdale, 'Population changes and the transfer of customary land'; Wrigley and Schofield, The population history of England, 376; Erickson, Women and property, 197.

82 Men remarried for similar reasons; see Erickson, Women and property, 195. 
83 Todd, 'Freebench and free enterprise', especially page 180; Alan Macfarlane, Marriage and love, 233, 284.

84 Brodsky, 'Widows in late Elizabethan London', 128; Erickson, Women and property, 196-8. Todd looked at remarriage among different bands of wealth, but compared only the wealthiest and least wealthy groups, and does not give figures the middling group her conclusion that 'Wealth seems to have had less effect on changing remarriage patterns than one would expect' can therefore be questioned; see Todd 'The remarrying widow', 66-8.

85 Wales, 'Poverty, poor relief and the life-cycle', 366.

86 See for instance Amussen, An ordered society, especially pages 34-66, and S. H. Rigby, English society in the later Middle Ages: class, status and gender (London, 1995), 243-83.

87 For instance, see Spufford, Contrasting communities, 115, and Todd, 'Freebench and free enterprise', 176

88 Whittle, 'The development of agrarian capitalism', 263-83.

89 Erickson, Women and property, 224-5.

90 The continuity in women's status and position has been commented on by Judith Bennett in 'Medieval women, modern women: across the great divide', in David Aers ed., Culture and history 1350-1600: essays on English communities, identities and writing (Hemel Hempstead, 1992), 147-75, and by Erickson in Women and property, 232. 